\title{
Design and Analysis on the internal factors of economic equilibrium index
}

\author{
Dailijun \\ Oxbridge of Kunming science and technological university \\ Yunnan Kunming, china
}

\begin{abstract}
- the economic equilibrium index is used to measure the relationship between national consumption, the growth rate of GDP and household savings, the government debt index. Through research we found that, the four economic indicators can only maintain a reasonable proportion of the condition of a country's economy is in the balance state. The sampling and investigation on the world through the economic data of some typical countries, and these countries in the sample is designed and computing method of economic equilibrium index, a reasonable level to measure the rate of economic growth and consumption, savings and government debt of the three, and can determine the reasonable choice of a country's economy in the economic the development level of consumption, savings and government debt levels according to the index, and maintain the balance of economic field.
\end{abstract}

Key words-equilibrium; consumption; savings; gross domestic product ( GDP); government debt

Economic imbalance is the cause of a country into the economic difficulties, economic imbalance is the direct factors causing fluctuations in the exchange rate, domestic economic development lack the motive force of the development of. However, people always realize economic imbalances when crisis appeared to in the reality, and not a reasonable method to predict the economic imbalance. In order to solve this problem, the members of the project group choose from some typical countries as samples on the economic data of world to analyze, and built the balanced economic index of the system, we hope to use this index to predict the potential risks to the imbalance of economic development, reduce the economic imbalance to the state caused by loss.

Through the research we found that, in recent years the occurrence of financial risk and debt crisis countries have a common characteristic: they are the slow pace of economic development, but the proportion of government debt built up a long time is very high. When the lower economic growth with higher government debt crisis also begins. On the other hand, consumption and savings is the impact of economic equilibrium level of a factor, because the government debt levels are relatively high and national savings rate is relatively low, but their consumption level is very high, Due to there is a good social welfare system, domestic residents accustomed to high level of welfare conditions high consumption expenditure, when the government revenue can not support the welfare spending only by borrowing to support their public welfare spending, low income and high expenditure form the basic conditions of the debt crisis, and caused serious economic

\author{
MaoXiaoLi \\ Oxbridge of Kunming science and technological university \\ Yunnan Kunming, china
}

crisis, especially when unable to repay the debt. Therefore, economic equilibrium index the content should include at least the GDP growth rate, consumption, savings and government debt level of four parts. The following is the analysis of national economic index sample we selected.

\section{I.THE GROWTH RATE OF GDP AND THE LEVEL OF GOVERNMENT DEBT}

Total debt to the absolute number of in fact does not show the degree of risk of government debt, as we cannot judge a person's level of debt is more 100 yuan or 1000 yuan more? Personal debt level and the degree of risk depends on the level of his income, for a no income people 100 yuan debt is very high, but the income of 4000 yuan a month for the people, 1000 yuan of debt is not a problem. The government's debt level is the same reason, indebted amount itself is not a problem, the key is to control the amount of liabilities and reasonable ratio between the levels of economic growth, if a country has good economic development speed, and has considerable economic benefits, so even if it's high level of indebtedness is normal, as long as it has sufficient ability to repay is no problem. But the slow economic development for the country, even a small increase in government debt will cause the repayment risk. So the reasonable proportion of GDP growth and the level of government debt levels are important factors to keep the economic balance, when we consider the economic equilibrium is necessary to observe the rate of economic growth and the level of government debt structure is reasonable?

New data from the world bank to analyze, from 2008 to 2011 four years China 's average GDP growth rate of 9.63\%, India, 7.15\%, Luxemburg $0.05 \%$, the Greek $-3.83 \%$, Japan $-0.7 \%$, Iceland $-1.05 \%$, France $0.05 \%$, the United States $0.2 \%$. In these countries, China, India, Luxemburg government debt levels are rational, Greece, Japan, Italy, the level of government debt accounted for the proportion of GDP is more than $100 \%$. Such as Iceland's government debt levels for the GDP ratio reached $111.7 \%$, the Greek accounted for $131.5 \%$, Italy accounted for $117.3 \%$, The French government debt as a share of GDP reached $88 \%$, the United States of America reached $76.8 \%$, while Spain their debt levels in a short span of three years from $30.1 \%$ rises to $48.3 \%$. In these countries the United States has been a very addicted to deficit countries, rely on issuing bonds and overdraft spending once the American economy has done very well. 
In Europe, many countries on such debt finance is used, and have followed suit, can also is these reassuring developed countries because of the government the defaulted on their debt trouble. The debt we cannot predict what will the impact of Asian economy and the world economy is even more worried about Japanese level of debt accounted for the proportion of GDP up to $175 \%$ ? If Japanese debt crisis will produce what kind of consequences? This will also be a challenge for Asian countries?

The following is the world average GDP nearly four years of growth rate and the ratio of government debt to GDP, through these data, we can analyze the reasonable proportion of economic growth and debt levels.

\begin{tabular}{||l|c|c||}
\hline \hline Country name & nearly four years of & The ratio of government \\
\hline China & 9.625 & \\
\hline India & 7.15 & 47.3 \\
\hline Luxembur & -0.05 & 16.8 \\
\hline Greece & -3.825 & 134.5 \\
\hline Germany & 0.8 & 55.6 \\
\hline Japan & -0.7 & 175 \\
\hline France & 0.05 & 88.4 \\
\hline America & 0.2 & 77 \\
\hline Iceland & -1.05 & 119.3 \\
\hline spain & -0.675 & 87 \\
\hline Italy & -1.125 & 117.3 \\
\hline Sweden & 1.225 & 39.2 \\
\hline Denmark & -0.95 & 44 \\
\hline
\end{tabular}

From this set of data we can know, China and India due to the high economic growth rate and more reasonable government debt levels, their economic growth and government debt problem basically maintained a balance, Luxemburg, Sweden, Denmark, Germany's economic growth of China and India, although not as strong, but to rely on a balanced economic reasonable debt levels are also stable. However, in recent years have debt crisis countries such as Greece, France, Iceland, Spain and Italy because of high government debt and economic growth level of the domestic economy appear larger fluctuation, and fell into a debt crisis. In another word, imbalance between debt level and the level of economic development. Key debt amount is not a problem, it is important to government debt capacity and coordination, is to adapt and the solvency of the government. As long as the government reimburses ability within the scale of debt is reasonable. Let us analyze the residents' savings and consumption problem.

\section{II.THE RESIDENTS OF THE DAILY CONSUMPTION SPENDING AND SAVING ANALYSIS}

Consumption and savings is a national wealth accumulation and use of the two aspects, both for the country and the individual, modest savings and moderate consumption is an important means to keep the economic balance, as economic growth and government debt, consumption and savings must be reasonable in a certain level of conservation can only sustain economic equilibrium, the level of consumption high savings will increase the level of debt, and saving too much consumption deficiency could inhibit the growth of the space, and the lack of potential economic growth.

\begin{tabular}{||l|l|l||}
\hline \hline Country name & $\begin{array}{l}\text { Savings accounts for } \\
\text { the proportion of } \\
\text { GDP (\%) }\end{array}$ & $\begin{array}{l}\text { Household final consumption } \\
\text { accounted for the proportion } \\
\text { of GDP (\%) }\end{array}$ \\
\hline China & 53 & 34 \\
\hline India & 31 & 57 \\
\hline Luxemburg & 52 & 31 \\
\hline Greece & 8 & 75 \\
\hline Germany & 23 & 57 \\
\hline Japan & 19 & 60 \\
\hline France & 18 & 58 \\
\hline America & 11 & 72 \\
\hline Iceland & 23 & 52 \\
\hline spain & 21 & 58 \\
\hline Italy & 18 & 61 \\
\hline Sweden & 26 & 48 \\
\hline Denmark & 23 & 49 \\
\hline
\end{tabular}

In the process of our sample countries residents' consumption and savings levels were in the survey we found two such cases, one is the high savings and low consumption in countries such as China savings account for $53 \%$ of GDP, but the consumption the proportion of GDP accounted for only 34\%, Luxemburg's level of savings account for $52 \%$ of GDP ,the consumption which accounted for $31 \%$ of GDP, but the average consumption level of Luxemburg's is about 25 times higher than China's per capita level. The second is of low savings and high consumption such as India's savings rate of $31 \%$, consumption accounted for $57 \%$, the savings rate is $8 \%$, but consumption accounted for the proportion of GDP up to $75 \%$, the United States savings rate of $11 \%$, consumption accounted for $72 \%$. Of course, we also found, most of the world's countries in fact belong to low savings and high consumption of the country, only in some very much savings and the economic development better stable countries we found that the high savings phenomenon. Savings and consumption should be in a reasonable range that do not threaten economic stability of a country.

First we analyze the high savings and low consumption of the country will appear what kind of economic problems? To use the national income from the traditional meaning is composed of two parts, one part for daily consumption, the other part is used for savings. In a country like China, it has long been influenced by traditional culture deeply, people always regard saving as a very necessary thing, in the effect of traditional culture under the Chinese made high domestic savings. However, we also found that China's per capita consumption level is very low, according to the statistical data in 2011, the world bank, the average amount of daily consumption of Chinese year of only $\$ 949$, about the per capita consumption of $1 / 30$ of the United States of America. The high savings rate can greatly reduce the number of such 
government spending on social welfare level, reduce the pressure of fiscal expenditure of government, but on the other hand, the total demand for low consumption level will restrain the economic development, and the lack of sustained development. China at this stage of the domestic consumption scale mainly comes from the large number of consumer population, rather than from the high level of consumption. Luxemburg is also a high savings and low consumption country, but with the Chinese on the contrary, Luxemburg's consumption from a small population of high consumption, high savings rate from the lucrative income per capita.

In fact, most countries in the world are low savings and high consumption countries, analysis from the angle of economics, labor is the fundamental activity to survive, to engage in labor and most income for living expenses is an inevitable choice. The United States National is used to the future income on today to spend, in very long period of time, this idea stimulated the United States domestic social needs, but also to let the United States economic benefit, was to stimulate rapid economic growth strength. However, we should note that, consumption level and income level should suit is rational, if excessive consumption will affect the economic balance, for individuals, if people are spending money and not pay attention to saving will increase their level of debt, but for a government, if excessive consumption and the corresponding lack of capacity to pay will be a debt crisis, debt crisis in recent years, the United States, France, Greece, Italy, Spain is a low savings and high consumption of the country. Low saving rate in fact means that residents rely more on the government to provide social welfare safeguard of life through the crisis stage, when the sound economic development, government revenue adequacy of such social welfare of course is the best, but, when the speed of economic downturn caused when government revenue reduce a large number of social welfare spending should how to maintain? The answer is only two, or the issuance of bonds, either to reduce welfare expenses. In fact, we all know, regardless of the choice of countermeasures which are not the best.

The point needs to be emphasized: the savings rate is high and low do not represent the residents of a country's level of affluence, the consumption rate is independent of the consumption level of residents. High savings rate countries are likely to be in poor countries, also has the possibility is the rich countries, which related to their income levels, we can not simply use the savings rate to measure the wealthier residents, and to combine their income level to judge the residents level of wealth. The consumption rate is relative in terms of income, the fact that the share of consumption in GDP only shows one aspect of resident consumption level, consumption level have to combine their income level analysis, if the residents consumption but income level is very low, only can prove his consumption level is not high.

\section{THE INDEX METHOD IS ILLUSTRATED}

Economic equilibrium index is not a single data, but a set of economic indicators system, it includes the gross domestic product, the level of government debt, savings of residents and residents of the daily consumption of four basic indicators. When we only analyze the one or two indexes are unable to judge a country's economic development level, only the economic equilibrium level to measure a country's comprehensive portfolio to these indicators. Methods that only use GDP growth rate the quality of economic development there is a big loophole, more people want to see the quality of economic development in the economic growth rate, economic equilibrium index is designed in order to realize this goal, because economic growth is not only to the pursuit of speed, more to the pursuit of quality, with low quality for the price the mode of economic development will be eliminated in the future crises.

According to the data provided by the world bank, the thirteen countries in the world economic data sampling analysis, stresses that the thirteen countries in our sample of GDP growth rate, the level of government debt, savings of residents and residents of the daily consumption of four basic indicators of specific analysis, these countries are typical in the aspect of economy in recent years, some countries produced crisis, some countries developed to a stable state, we to these countries economic indicators for the mathematical treatment, we obtain an explicit index, also is the index of economic equilibrium, this index can reflect a country in economic equilibrium level, believe in we have a choice of countries is equally effective. The design of balanced economic indicators of the following steps:

1. To one country nearly four years the growth rate of GDP average value calculated.

2. With the average GDP growth rate and the level of government debt, savings of residents and residents of the daily consumption by comparing the original index of economic equilibrium.

3 . The original economic equilibrium index for mathematical treatment to obtain the final economic equilibrium index.

The hypothesis of economic equilibrium index was $\mathrm{E}$, the ratio of government debt to GDP is B, savings accounts for the proportion of GDP to S, the resident daily consumption as a percentage of GDP is C, then the

$$
E=\sum_{i=1}^{4} G D P / 4 \times 10+S-B-C+100
$$

The coefficient in the formula 10 and 100 just for mathematical convenience and degree of formula of coordinate axis adjustment, they have no economic significance.

According to the economic equilibrium index derived formula, we selected 13 sample countries economic 
equilibrium index were calculated, and the calculation results:

\begin{tabular}{|c|c|c|}
\hline Country name & $\begin{array}{ll}\text { Theo } & \text { riginal } \\
\text { equilibrium } & \text { index }\end{array}$ & $\begin{array}{l}\text { The } \\
\text { equilibrium index } \\
\text { (E) }\end{array}$ \\
\hline China & 115.25 & 215.25 \\
\hline India & -1.8 & 98.2 \\
\hline Luxemburg & 3.7 & 103.7 \\
\hline Greece & -239.75 & -139.75 \\
\hline Germany & -81.6 & 18.4 \\
\hline Japan & -223 & -123 \\
\hline France & $\begin{array}{l}-127.9 \\
\end{array}$ & -27.9 \\
\hline America & -136 & -36 \\
\hline Iceland & -158.8 & -58.8 \\
\hline spain & -130.75 & -30.75 \\
\hline Italy & -171.55 & -71.55 \\
\hline Sweden & -48.95 & 51.05 \\
\hline Denmark & -79.5 & 20.5 \\
\hline
\end{tabular}

Value from the final equilibrium index " $E$ " we can see, China, India, the Luxemburg index, Germany, Denmark and Sweden is greater than zero, Greece, Japan, the United States, France, Iceland and Spain and other countries economic equilibrium index is less than zero. A numerical index $\mathrm{E}$ balance of economy to zero as the equilibrium point, from absolute zero is large, the possibility of economic imbalances is higher, if the equilibrium index is large, then there is no domestic have more potential for economic development play a role, there is part of the social wealth is not into the cycle of social reproduction, social resources waste or idle; if the equilibrium index is smaller, then the economic income and expenditure levels appeared deviation, the government may face debt risk, there is insufficient revenue risk. Economic equilibrium index " $\mathrm{E}$ " in the near zero indicates that stable economy is relatively good.

We can also according to the measured data using graphics to economic analysis of the equilibrium level of various countries.

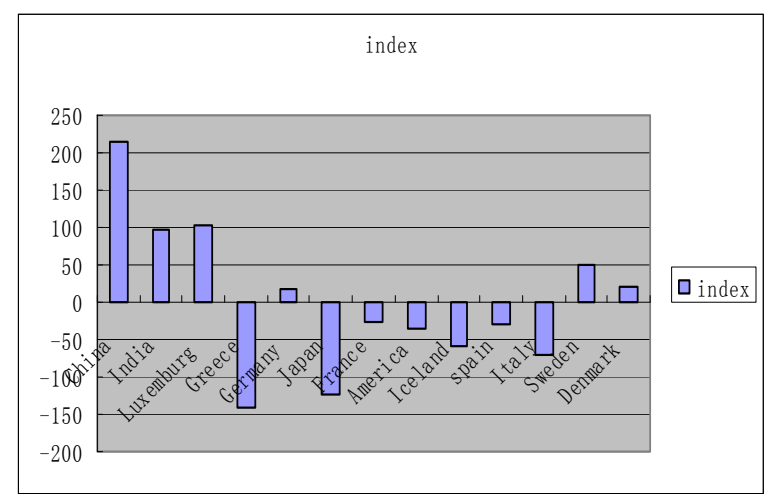

\section{ANALYSIS OF THE ECONOMIC INDICATORS OF THE OVERALL BALANCE}

We have on economic growth and government debt, savings and consumption are the two affects economic growth through the analysis of the factors, but the need to explain a little, these two aspects are not isolated, four economic factors we studied is not alone could influence the economic equilibrium level in economic equilibrium. For example, although GDP is growing very fast, but the government debt amount is bigger, this will also enable the government to face the risk of a debt crisis; on the contrary, if the GDP growth rate is not fast, the management mechanism on the rational control of the debt levels can still effectively control the government debt risk. Another example is: if a country's economic growth is faster, but residents are not willing to consumption, and put much of their income to savings will make domestic consumption market is facing the problem of insufficient demand, and will further suppress their next period of economic growth space.

The reason why we put forward this view to illustrate: economic equilibrium does not depend on one or two simple economic indicators can be achieved, the economic equilibrium realization must rely on a set of reasonable economic indicators as the basis. In different countries and we will find that there are different levels of economic development, economic equilibrium does not mean speed the pace of economic development or economic gross more with less, we put forward the economic equilibrium index system is in reasonable proportion to predict the economic development level of government debt, resident consumption and savings, in this index system, the speed of economic development is not the focus of our observations, our goal is to measure a country's overall economic development, whether reasonable, whether the balance. Whether economic equilibrium level in rich and poor countries need a reasonable, rich countries also will appear unbalanced economic development, while the poor countries in a certain period of time will be relatively stable. Measuring economic equilibrium index is a stable level of economic development, rather than wealth level.

\section{ACKNOWLEDGMENT}

Project name:Equilibrium about social welfare and personal consumption

Project comes from education department of Yunan .China.. project code :2012z154c

[1] Gaohongye, western economics, Renming university publisher ,2010 p45-47

[2] Ben s.Bernanke.Essays on the great depression.Dongbei University of finance and Economic press 2007

[3] human development report UNDP , 2011

[4] Tiglitz, Economics of the publisher sector, 2nd ,Norton NEW YORK 1988

[5] Benn steil,Robert E.Litan,The role of financial markets in American foreign policy. Dongbei University of finance and Economic press 2007

[6] The Economic way of thinking, paul heyne, world book publisher , 2008

[7] Economic math, Xiayong, Wang xiaokong, Qinghua university publisher ,2003

[8] Zengkanghua.Finance.Beijing.Economic publisher 2009 